\title{
Measurement of ferritin in serum by radioimmunoassay
}

\author{
M. D. BARNETT, Y. B. GORDON ${ }^{1}$, J. A. L. AMESS, AND D. L. MOLLIN \\ From the Departments of Haematology and Reproductive Physiology ${ }^{1}$, The Medical College of \\ St. Bartholomew's Hospital, London EC1A 7BE, UK
}

SUMMARY A method for the measurement of circulating ferritin concentrations by direct radio- $\dot{\omega}$ immunoassay is presented. The method described is simple to operate, precise, and sensitive and is suitable for the routine diagnostic measurement of ferritin in either plasma or serum.

Ferritin is the major intracellular iron storage protein found in the body, consisting of a spherical protein shell of MW 450000 made up of 24 identical subunits. Iron is stored in the inner core as crystalline ferric-oxide-phosphate. Ferritin is found mainly in the reticuloendothelial system, predominantly in the spleen, liver, and bone marrow. Circulating levels of ferritin have been shown to reflect the total body iron stores in most clinical situations (Walters et al., 1973; Bentley and Williams, 1974) with the exception of familial varieties of haemochromatosis (Wands et al., 1976).

A number of sensitive radioisotopic assays have now been described for measuring ferritin in plasma or serum. All have been based on an immunoradiometric technique in which the antibody to ferritin is labelled with iodine-125 (Addison et al., 1972; Miles et al., 1974; Halliday et al., 1975). The major advantage of this immunoradiometric technique over previously described methods is that it is sensitive enough to measure normal circulating levels of ferritin. Unfortunately, like many immunoradiometric methods, this technique may be time-consuming and imprecise and show inter-assay variation in results. Recent radioimmunoassays have been described for use in man in which ferritin itself was labelled with 125 I (Marcus and Zinberg, 1975; Luxton et al., 1977).

The present paper confirms and extends the use of direct radioimmunoassays for measuring ferritin in human serum or plasma. This technique is sufficiently sensitive to detect circulating levels within the normal range, it is easier to perform, and is more reproducible and economical than the immunoradiometric methods in current use.

Received for publication 29 June 1977

\section{Material and methods}

\section{REAGENTS}

Phosphate buffered saline (PBS) $0.15 \mathrm{M}$ phosphate $\frac{\bar{\rho}}{\oplus}$ buffer, pH 7·8, containing $9 \mathrm{~g} / 1$ sodium chloride and 2 ppm sodium azide.

Assay diluent-PBS containing $1 \mathrm{mg} / \mathrm{ml}$ bovine serum albumin (Sigma RIA grade).

Donkey anti-rabbit serum (DARS) (RD 17, Wellcome Reagents Ltd, Beckenham, Kent).

Normal (inactivated) rabbit serum (NRS) (TC 69, Wellcome Reagents Ltd, Beckenham, Kent).

PREPARATION OF HUMAN LIVER FERRITIN Human liver ferritin was prepared by a modification of the method of Aherne and Worwood (1974). Liver, obtained at necropsy from a patient with myocardial infarction, was homogenised, the mixture was heated to $70^{\circ} \mathrm{C}$, and the supernatant was subjected to ammonium sulphate precipitation. The pellet obtained after high-speed centrifugation was dissolved in PBS and subjected to gel-filtration on a calibrated column of Agarose A5-m (Bio-rad Laboratories). The fractions containing a red-brown $\frac{I}{O}$ protein with a molecular weight corresponding to monomeric ferritin were pooled and concentrated $\mathrm{N}$ by ultrafiltration.

The protein concentration of the ultrafiltrate $N$ was estimated by the method of Lowry et al. (1951). $\omega$ The purity was demonstrated by polyacrylamide disc gel electrophoresis using a $4 \%$ gel at $\mathrm{pH} 8.9$, and the immunospecificity was demonstrated by $\mathscr{\Phi}$ two-dimensional immunoelectrophoresis (Clarke and Freeman, 1968) against antiferritin antiserum and against anti-whole human serum.

PREPARATION OF ${ }^{125}$ I-LABELLED FERRITIN Human liver ferritin was iodinated by a modification 
of the technique described by Hunter and Greenwood (1962). Ten microgrammes of ferritin in $10 \mu \mathrm{l}$ PBS and $10 \mu \mathrm{l}$ of $0.4 \mathrm{M}$ phosphate buffer, $\mathrm{pH} 7 \cdot 4$, was added to $1 \mathrm{mCi}$ sodium ${ }^{125} \mathrm{I}$ (Code No. IMS 30, Radiochemical Centre, Amersham) in a tapered polystyrene tube followed by $10 \mu \mathrm{l}$ PBS containing $50 \mu \mathrm{g}$ chloramine-T. After mixing for 30 seconds a further $20 \mu \mathrm{l}$ PBS containing $60 \mu \mathrm{g}$ sodium metabisulphite was added, followed by $100 \mu l$ assay diluent. The percentage incorporation of ${ }^{125} \mathrm{I}$ into protein for each radioiodination was calculated using paper wick chromatography (Ørskov, 1967). Five microlitres of the iodination reaction mixture was applied to a strip of Gelman paper $(3-8 \times 11)$. The wick was placed in a test tube containing $1 \mathrm{ml}$ $5 \%$ trichloroacetic acid for 15 minutes. The paper was then cut into $1-\mathrm{cm}$ strips, and the radioactivity was counted.

The iodination reaction mixture was purified by gel-filtration using an Agarose A5-m column eluted with assay diluent. The immunoreactivity of the labelled products in the column fractions was assessed by determining the percentage that was bound by an excess of antihuman ferritin antibody (Fig. 1). Fifty microlitres of each fraction was diluted in $1 \mathrm{ml}$ assay diluent, and $100 \mu \mathrm{l}$ of this was added to $100 \mu \mathrm{l}$ of antiferritin antiserum to give a final antiserum dilution of 1:1000. After incubation for $2 \mathrm{~h}$ at $37^{\circ} \mathrm{C}$ the antibody bound and free protein were separated as described below. Control tubes containing no antiserum but the same concentration $(1: 1000)$ of normal serum (NRS) were included. The fractions containing the highest immunoreactivity were pooled, divided into aliquots, and stored at $-20^{\circ} \mathrm{C}$. The binding was assessed on each aliquot, after thawing, before use in the assay to assess the stability of the 125I-labelled ferritin; however, the final antiserum dilution was increased to $1: 2 \times 10^{6}$ to correspond with the conditions used in the routine assay.

\section{SEPARATION OF BOUND AND FREE}

${ }^{125}$ I-LABELLED PROTEIN

The effect of using various concentrations of the different reagents was studied, and the suitability at each concentration was assessed using the criteria of Chard (1971). The incubation mixture in all the experiments contained $1 \mathrm{ng}$ of ${ }^{125} \mathrm{I}$-labelled ferritin and a final dilution of antiferritin antibody of $1: 1000$ in a final volume of $500 \mu \mathrm{l}$. Control tubes containing no antibody but a similar concentration $(1: 1000)$ of normal rabbit sera (NRS) were included.

In the second antibody precipitation technique, varying concentrations of donkey anti-rabbit serum were added to each tube followed by varying concentrations of normal rabbit serum. After an

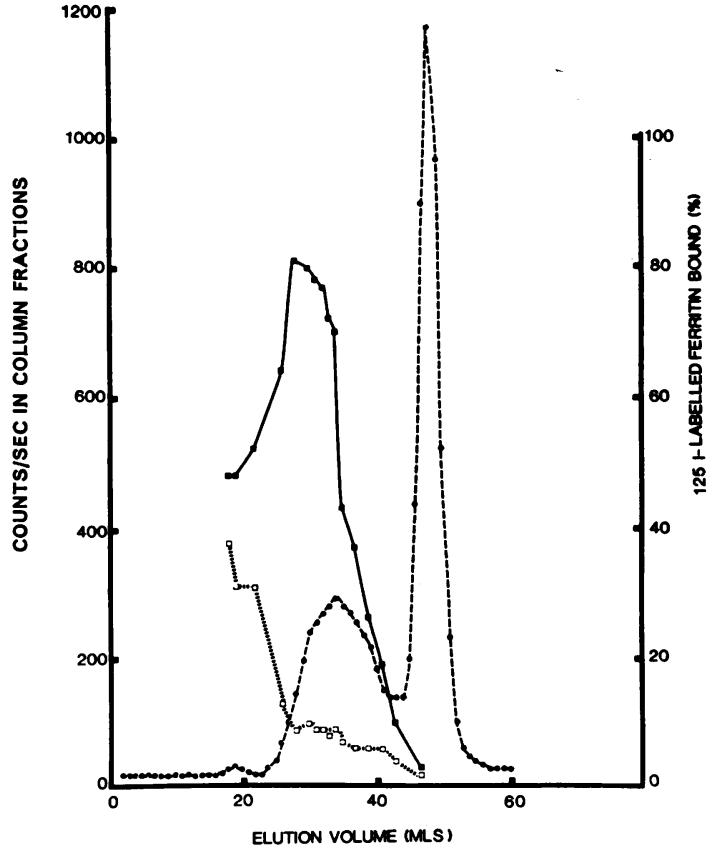

Fig. 1 Separation of ${ }^{125}$ I-labelled ferritin from other components of the iodination mixture using Agarose- $A 5 \mathrm{~m}$. The distribution of radioactivity (- - ), the percentage binding in antibody excess ( $(-$ and the non-specific binding (.......) are shown. The first peak was due to iodination-damaged ferritin aggregate, the second to monomeric labelled peptide, and the third to unreacted ${ }^{125} \mathrm{I}$.

incubation at $37^{\circ} \mathrm{C}$ for $2 \mathrm{~h}$ the reaction tubes were centrifuged at $2500 \mathrm{~g}$ for $30 \mathrm{~min}$ at $4^{\circ} \mathrm{C}$; the supernatant was discarded and the precipitate containing the antibody-bound ferritin was counted.

For the fractional precipitation method, increasing volumes of ethanol or ammonium sulphate (Chard et al., 1971) or polyethylene glycol (6000) (Desbuquois and Aurbach, 1971) were used. In each case $50 \mu \mathrm{l}$ horse gammaglobulin was added to provide a visible precipitate.

On the basis of these results the second antibody precipitation method was selected and used in all subsequent experiments.

\section{PRODUCTION AND ASSESSMENT OF ANTISERA}

Adult New Zealand White rabbits were immunised with the purified human liver ferritin. For both the initial and subsequent booster injections each rabbit received $500 \mu \mathrm{g}$ of ferritin, prepared as a water-in-oil emulsion by mixing two volumes of 
complete Freund's adjuvant (Difco Laboratories, Detroit, Michigan) with one volume of buffered ferritin. One millilitre of this emulsion was injected into multiple subcutaneous sites in the neck at intervals of four to seven weeks. Blood was obtained from an ear vein 28 days after primary immunisation and 14 days after boosting.

The antibody titre of the sera was assessed by measuring the binding to ${ }^{125}$ I-labelled ferritin. Antiserum dilution curves were constructed by setting up doubling dilutions of the antisera to be tested in $450 \mu$ l assay diluent, followed by the addition of $50 \mu \mathrm{l}$ of suitable dilution 125I-labelled ferritin $(0.5-1 \mathrm{ng})$. The tubes were incubated for $18 \mathrm{~h}$ at $20^{\circ} \mathrm{C}$ before the addition of second antibody and a further incubation for $2 \mathrm{~h}$ at $37^{\circ} \mathrm{C}$ before final separation. Control tubes (diluent blanks) were set up without antiferritin antibody. The titre of the sera was defined as the dilution which bound $50 \%$ homologous labelled ferritin.

For the construction of standard curves, $50 \mu \mathrm{l}$ of doubling dilutions of a standard unlabelled ferritin solution $(2 \cdot 5-350 \mu \mathrm{g} / \mathrm{l})$ were added to $350 \mu \mathrm{l}$ of the assay diluent followed by $50 \mu 1$ of a suitable dilution of ${ }^{125}$ I-labelled ferritin $(0.5-1.0 \mathrm{ng}, 10000 \mathrm{cpm})$ in assay diluent also containing 1:1000 normal rabbit sera and, finally $50 \mu \mathrm{l}$ of specific antiserum diluted to give a final dilution ranging from $1 \times 10^{4}$ to $1 \times 10^{8}$. Control tubes were prepared as described above (diluent blank) as well as zero standards (no unlabelled ferritin). The tubes were incubated for $18 \mathrm{~h}$ at $4^{\circ} \mathrm{C}$ before the addition of second antibody and a further incubation of $2 \mathrm{~h}$ at $37^{\circ} \mathrm{C}$ before the final separation of bound and free ${ }^{125}$ I-labelled ferritin.

PREPARATION OF FERRITIN-FREE SERA

Ferritin-free human sera were prepared by immunoabsorption. Glutaraldehyde cross-linked rabbit antiferritin antibody was prepared according to the method of Avrameas and Ternynck (1969). The IgG fraction of rabbit antiferritin antiserum was suspended in $0.15 \mathrm{M} \mathrm{NaCl}$ and the $\mathrm{pH}$ was adjusted to 8.0 with $0.1 \mathrm{M} \mathrm{NaOH}$. A $25 \%$ solution of glutaraldehyde was added to give a final concentration of 1 part protein : 10 parts glutaraldehyde, mixed, and left at room temperature for one hour. The conjugated protein was centrifuged, resuspended in $0.15 \mathrm{M} \mathrm{NaCl}$, and washed. The conjugate was then added in excess to the serum, which had been trace labelled with ${ }^{125}$ I-labelled ferritin. The serum was mixed at $4^{\circ} \mathrm{C}$ for $48 \mathrm{~h}$ and centrifuged to remove the conjugated IgG-ferritin complex. The effectiveness of ferritin removal was assessed by measuring the concentration of ferritin and by counting the radioactivity before and after conjugation.
SUBJECTS STUDIED AND PROCEDURE Sixty-five subjects were randomly selected from patients who had had a bone marrow biopsy as a $\stackrel{0}{\rightarrow}$ part of a general haematological investigation. The group included patients with iron deficiency anaemia, megaloblastic anaemia, a combination of iron $\frac{\omega}{\vec{D}}$ deficiency and megaloblastic anaemia, anaemia of $\mathbb{Q}$ chronic disorder, sideroblastic anaemia, and transfusional haemosiderosis. Patients with leukaemia or other neoplastic diseases were excluded from this series.

Haemoglobin concentration, packed cell volume, erythrocyte count, mean cell volume, mean cell 용 haemoglobin, mean cell haemoglobin concentration, $\omega$ and leucocyte count were determined on sequestre- $\infty$ nated blood using a Coulter Counter model S, and the platelets were counted on a Technicon Auto- $\vec{N}$ Analyzer.

Serum iron concentration was measured by an automated micromethod (Garry and Owen, 1967) using a Technicon AutoAnalyzer and the unsaturated iron binding capacity using a semiauto- क mated micromethod with radioactive iron (Brozovic $\vec{\varphi}$ and Copestake, 1969). The measurement of serum $\infty$ and erythrocyte folate was carried out by a semiautomated microbiological assay using a chloramphenicol-resistant strain of Lactobacillus casei (Millbank et al., 1970). The vitamin $B_{12}$ concentration was measured by a microbiological assay using Euglena gracilis Z strain (Anderson, 1964). Other haematological methods were those described by Dacie and Lewis (1975). Ferritin in serum was assayed in duplicate, as described above.

\section{ASSESSMENT OF BONE MARROW IRON}

Iron, which is stainable by the Prussian blue reaction, is present in the reticulum cells of the bone marrow fragments of normal individuals. The amount of this intracellular iron in the bone marrow fragments can be used as a guide to the state of the iron stores of the body (Gale et al., 1963). The amount of stainable iron in the fragments of the patients studied was assessed by one observer (JALA) without previous knowledge of the clinical and $\tilde{\sigma}$ laboratory findings.

Stainable iron was graded as follows:

Grade 0 no visible iron

Grade 1+

Grade 2+ small numbers of iron particles present in the reticulum cells of the marrow fragments numerous small particles present in the reticulum cells throughout the marrow fragments with a tendency in some cases for the particles to aggregate into denser clumps 
Grade 3+ dense, large deposits of iron in the reticulum cells of the marrow fragments.

\section{Results}

EVALUATION OF PURIFIED FERRITIN

The human liver ferritin, prepared by the method described above, appeared to be immunologically pure. Only a single peak was found when the material was subjected to two-dimensional immunoelectrophoresis against antiferritin antiserum and against anti-whole serum. The peak stained for both iron and protein. The material also appeared pure on polyacrylamide disc gel electrophoresis at pH 8.9, giving a single band which stained for protein running in the same position as a ferritin standard.

EVALUATION OF ${ }^{125}$ I-LABELLED FERRITIN

Two radioactive peaks were found when the iodination mixture was subjected to wick chromatography; one peak, the precipitated protein, remained at the origin. The second faster moving peak was found in a position identical with the single peak that was obtained when ${ }^{125 I}$ was run alone. The mean percentage incorporation of ${ }^{125} I$ calculated from the results of wick chromatography was $33 \%$ (range $28-36 \%$ ), and the mean specific activity of the labelled ferritin was 33 (range 28-36) $\mu \mathrm{Ci} / \mu \mathrm{g}$ protein.

Chromatography of the iodination mixture on Agarose A5-m yielded three peaks of radioactivity (Fig. 1). Protein-bound radioactivity was confined to the first two peaks, as judged by the binding in antibody excess. The third peak was unreacted iodine. The first small peak of radioactivity showed high non-specific binding in the absence of antibody and probably represented aggregated material. The second, larger peak, however, demonstrated a low non-specific binding, and the maximum immunoreactivity occurred on the ascending limb of the peak. This probably represented intact monomeric ferritin, whereas in the descending portion of the peak degradation had probably taken place.

The 125I-labelled ferritin was stable for at least one month, as judged by its immunoreactivity. After this time there was a decrease in the binding of 125I-labelled ferritin with a concomitant rise in the non-specific binding (Fig. 2). Gel-filtration of the label stored at $-20^{\circ} \mathrm{C}$ for 60 days showed aggregation of the ferritin molecule, which accounted for the increase in non-specific binding, but the addition of disaggregating agents, storage at alternative temperatures, or freeze-drying did not enhance the stability of the preparation.

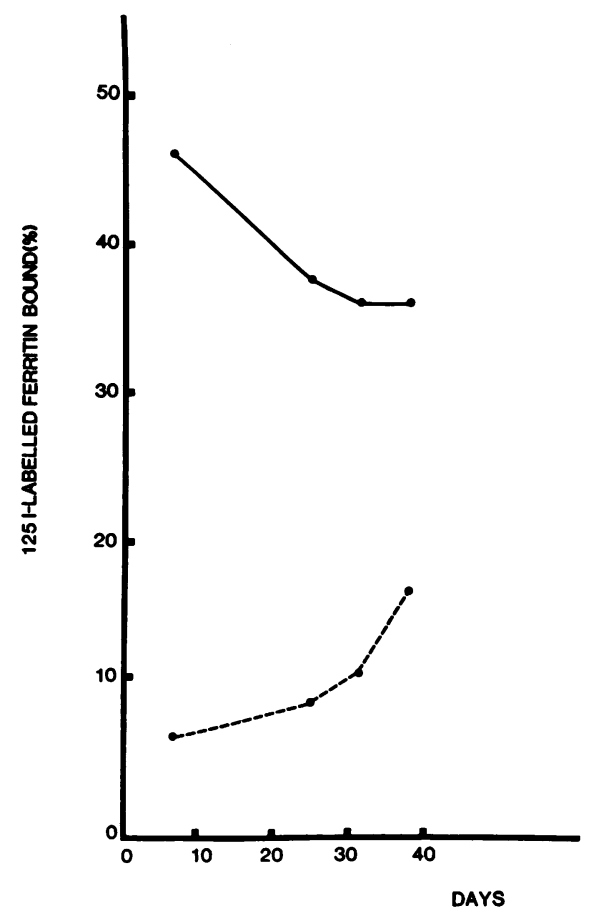

Fig. 2 Effect of storage at $-20^{\circ} \mathrm{C}$ on the binding of ${ }^{125}$ I-labelled ferritin and on the presence (-) and absence (- - ) of antibody.

\section{SEPARATION OF ANTIBODY-BOUND AND}

FREE ANTIGEN

The double antibody technique proved an efficient method for the separation of bound and free antigen. Maximum binding of ${ }^{125} \mathrm{I}$-labelled ferritin was acheived after a $2-\mathrm{h}$ second incubation at $37^{\circ} \mathrm{C}$, by using a final dilution of $1: 1000$ normal rabbit serum and 1:80 donkey anti-rabbit serum. The other methods were less suitable, because both free and antibody-bound 125 I-labelled ferritin were precipitated by the same concentrations of ammonium sulphate, ethanol, and PEG-6000.

FERRITIN-FREE SERUM

The results in the Table indicate that human ferritin

Table Effect of ferritin removal by

glutaraldehyde conjugated antiferritin antibody

\begin{tabular}{rll} 
& $\begin{array}{l}\text { Ferritin } \\
\text { concentration } \\
\text { ( } \mu \mathrm{g} / \mathrm{l})\end{array}$ & $\begin{array}{l}{ }^{125} \text { I added } \\
(\mathrm{cpm} / \mathrm{l})\end{array}$ \\
\hline Pre-conjugation (a)* & 10.0 & $2.92 \times 10^{4}$ \\
(b) & 15.0 & $3.68 \times 10^{4}$ \\
Post-conjugation (a) & $<5.0$ & $0.24 \times 10^{4}$ \\
(b) & $<5.0$ & $0.29 \times 10^{4}$ \\
\hline
\end{tabular}

*Two normal human sera $(a, b)$ were used. 
was removed by treating two human sera with glutaraldehyde-conjugated IgG specific to human ferritin. Ferritin could not be demonstrated by radioimmunoassay after such treatment, and less than $10 \%$ of the added radioactivity could be detected after immunoadsorption. Standard curves using both preparations of ferritin-free sera for the dilution of the standards were identical.

EVALUATION OF ANTISERA AND

SENSITIVITY OF ASSAY

All rabbits developed antibodies, and in each case the titre rose after booster injections. The highest titres, defined as $50 \%$ binding with respect to homologous labelled ferritin, ranged from $2 \times 10^{6}$ to $2 \times 10^{\text {? }}$.

A series of standard curves was tested against varying dilutions of antiserum ranging from 1 in $1 \times 10^{4}$ to 1 in $1 \times 10^{8}$. When a final concentration of 1 in $2 \times 10^{6}$ antibody was used with labelled ferritin sufficient to give $10000 \mathrm{cpm}(0 \cdot 5-1 \mathrm{ng})$ and with a first incubation of $16 \mathrm{~h}$ at $4^{\circ} \mathrm{C}$, the results of 10 consecutive assays (mean \pm SD) showed a detection limit of $5 \mu \mathrm{g} / \mathrm{l}$ (Fig. 3). This dilution was used for the measurement of ferritin in serum in normal subjects with standards which ranged from 2.5 to $350 \mu \mathrm{g} / \mathrm{l}$. If the circulating level of ferritin was above $350 \mu \mathrm{g} / \mathrm{l}$ the samples were further diluted in ferritin-free serum and reassayed.

Quality control sera were included in every assay for the assessment of inter-assay and intra-assay variation. The intra-assay coefficient of variation

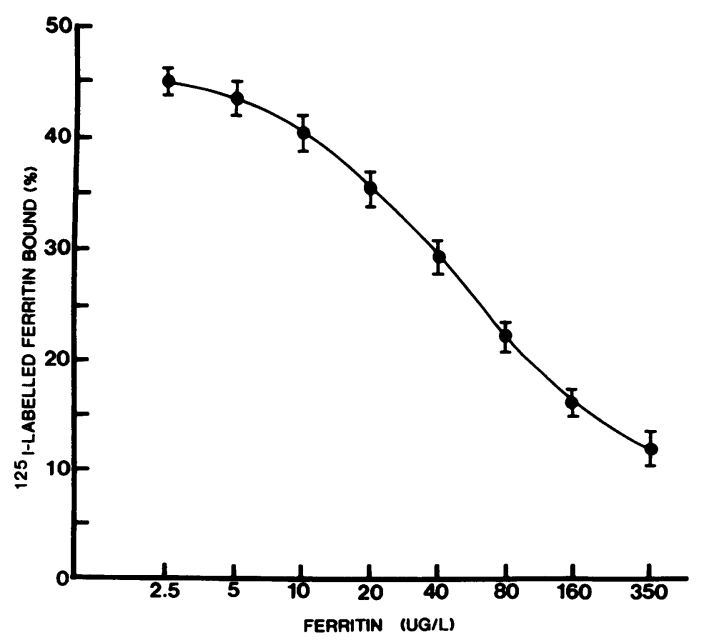

Fig. 3 A mean $\pm S D$ of 10 standard curves for the routine measurement of ferritin. The tubes contained ${ }^{125}$ I-labelled tracer adjusted to give $10000 \mathrm{cpm}$ (0.5-1ng), a final dilution of antiserum of 1 in $2 \times 10^{6}$, and required a 16- $h$ incubation at $4^{\circ} \mathrm{C}$. of sera with ferritin concentrations of 15,40 , and $56 \mu \mathrm{g} / \mathrm{l}$, each assayed 10 times, were $8 \cdot 0,2 \cdot 7$, and $1.8 \%$ respectively. The inter-assay coefficients of variation of four sera assayed in duplicate on 20 occasions with ferritin concentrations of $10,33,51$, and $108 \mu \mathrm{g} / 1$ were $14,6,5$, and $3 \%$, respectively, over a six-month period.

Ten serum samples with starting values greater than $350 \mu \mathrm{g} / \mathrm{l}$ were subjected to a series of doubling dilutions in both buffer and ferritin-free serum. The dose response curves in both buffer and serum were parallel on visual inspection to those found when the purified ferritin standards were assayed. Six recovery experiments were performed by the addition of between 25 and $220 \mu \mathrm{g} / 1$ ferritin to the normal assay standards. The median recovery was $103 \%$ and the range was 88 to $122 \%$.

\section{RELATIONSHIP BETWEEN SERUM}

FERRITIN AND IRON STATUS

The 65 patients studied were classified into four groups according to the amount of iron present in their bone marrow using the following grades. Twenty-one patients were grade 0 , eight patients were grade $1+, 29$ were grade $2+$, and the remaining seven were grade $3+$. The ferritin levels in each group are shown in Figure 4.

There was a progressive increase in the serum ferritin levels between grade 0 and grade $3+$ bone marrow iron stains, and although there was some overlap between grades $1+$ and $2+$ and between grades $2+$ and $3+$, no overlap existed when grade 0 was compared with either grade $1+$ or $3+$. The single patient in grade $2+$ with a serum ferritin level less than $5 \mu \mathrm{g} / 1$ suffered from a pyrexia of unknown origin, and the discrepancy could not easily be explained.

\section{Discussion}

The present paper confirms and extends the use of a direct radioimmunoassay for the measurement of circulating levels of ferritin in human serum or plasma (Marcus and Zinberg, 1975; Luxton et al., 1977). However, the assay described here is considerably more sensitive than that described by Marcus and Zinberg (1975), and this is the first time that a comparison has been made between serum ferritin levels measured by direct radioimmunoassay and total body iron stores assessed by staining of the bone marrow.

A number of specific problems were encountered during the development of the radioimmunoassay. Firstly, in the preparation of human liver ferritin an Agarose gel chromatography step was essential to obtain monomeric ferritin. If this was not done 


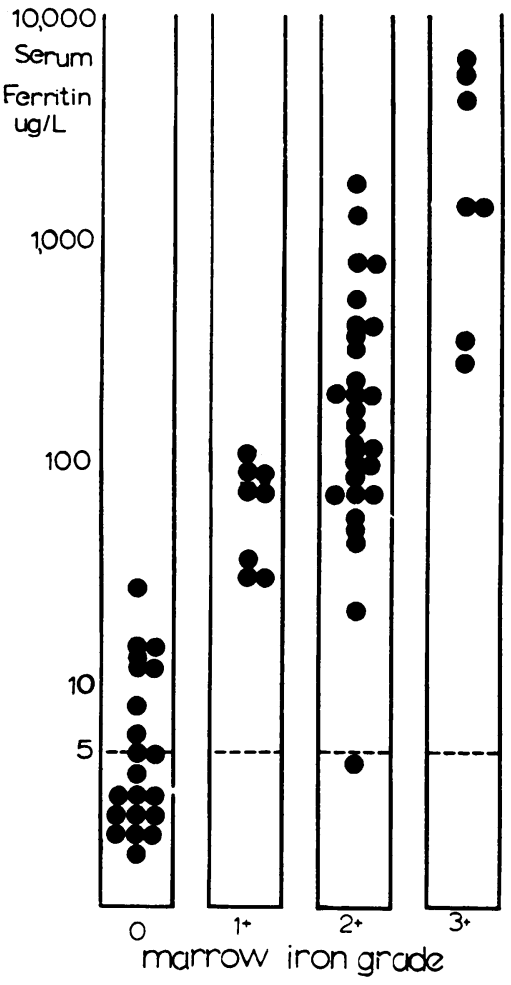

Fig. 4 Serum ferritin levels (O) in patients with a variety of bone marrow iron grades. The lower limit of detection of the assay is $5 \mu \mathrm{g} / \mathrm{l}$.

considerable difficulties occurred during the iodination with chloramine-T, and the resultant aggregated material interfered with the performance of the radioimmunoassay by creating high blank values and 'background' noise. Secondly, optimal incorporation of the 125I during the chloramine-T reaction was dependent upon the starting concentration of ferritin, and $1 \mu \mathrm{g} / \mu \mathrm{l}$ was found to be optimal. In addition, the purification of the iodinated material had to be carefully performed in order to remove the aggregate and to isolate the monomer peak. Thirdly, it was necessary to repeat the iodination every four weeks because of an increase in the blank value.

Apart from the difficulties described above the assay proved to be exceedingly stable and resilient, with a low inter-assay coefficient of variation. It was possible to prepare large batches of both standards and diluted antisera which appeared to be stable for at least six months. Although the second antibody separation technique required a two-hour incubation this could be reduced to five minutes by the addition of low concentrations of polyethylene glycol (Luxton et al., 1977). The preparation of highly specific and avid antisera presented no difficulty whatever, and the final dilution used in the routine assay was 1 in $2 \times 10^{6}$.

Serum ferritin in normal individuals is heterogenous and contains isoferritins characteristic of both liver and spleen apoferritin (Drysdale et al., 1977). The method described uses human liver as a source of ferritin for the tracer and standards, and in the production of antibodies. We have assumed, on the basis of the work of Drysdale and others, that splenic tissues could have been used as the source of ferritin.

In the patients studied, this assay showed that there was a good correlation between serum ferritin levels and stainable bone marrow iron. This has previously been described using an immunoradiometric method for the measurement of serum ferritin (Bentley and Williams, 1974; Hussein et al., 1975). The data presented suggest that the direct radioimmunoassay provided a reliable, precise, and robust method for the estimation of circulating levels of ferritin for use in the diagnosis of iron deficiency.

We thank Dr B. Brozovic for his invaluable encouragement and discussion, the staff of the diagnostic haematology laboratory who carried out haematological investigations of the subjects studied, and the Wellcome Trust for their financial support for this project.

Part of the data presented in this paper with a description of the method was first given at an Iron Club Meeting held at the Université Catholique de Louvain, Louvain-la-Neuve, Belgium, in April 1976.

\section{References}

Addison, G. M., Beamish, M. R., Hales, C. N., Hodgkins, M., Jacobs, A. and Llewellin, P. (1972). An immunoradiometric assay for ferritin in the serum of normal subjects and patients with iron deficiency and overload. Journal of Clinical Pathology, 25, 326-329.

Aherne, W., and Worwood, M. (1974). Some properties of human serum ferritin. Biochemical Society Transactions, 2, 429-432.

Anderson, B. B. (1964). Investigations into the Euglena method for the assay of vitamin $B_{12}$ in serum. Journal of Clinical Pathology, 17, 14-26

Avrameas, S., and Ternynck, T. (1969). The cross-linking of proteins with glutaraldehyde and its use for the preparation of immunoadsorbents. Immunochemistry, 6, 53-66.

Bentley, D. P., and Williams, P. (1974). Serum ferritin concentration as an index of storage iron in rheu- 
matoid arthritis. Journal of Clinical Pathology, 27, 786-788.

Brozovic, B., and Copestake, J. (1969). Semi-automated micromethod for estimating the unsaturated ironbinding capacity of serum using radioactive iron. Journal of Clinical Pathology, 22, 605-608.

Chard, T. (1971). Observations on the use of a mathematical model in radioimmunoassay. In Radioimmunoassay Methods, edited by K. E. Kirkham and W. M. Hunter, p. 595. Churchill Livingstone, Edinburgh.

Chard, T., Martin, M., and Landon, J. (1971). The separation of antibody bound from free peptides using ammonium sulphate and ethanol. In Radioimmunoassay Methods, edited by K. E. Kirkham and W. M. Hunter, p. 257. Churchill Livingstone, Edinburgh.

Clarke, H. G. M., and Freeman, T. (1968). Quantitative immunoelectrophoresis of human serum proteins. Clinical Science, 35, 403-413.

Dacie, J. V., and Lewis, S. M. (1975). Practical Haematology, 5th edition. Churchill Livingstone, Edinburgh.

Desbuquois, B., and Aurbach, G. D. (1971). Use of polyethylene glycol to separate free and antibody bound peptide hormones in radioimmunoassay. Journal of Clinical Endocrinology and Metabolism, 33, $732-744$.

Drysdale, J. W., Adelman, T. G., Arosio, P., Casareale, D., Fitzpatrick, P., Hazard, J. T., and Yokata, M. (1977). Human isoferritins in normal and disease states. Seminars in Haematology, 14, 71-88.

Gale, E., Torrance, J., and Bothwell, T. (1963). The quantitative estimation of total iron stores in human bone marrow. Journal of Clinical Investigation, 42, 1076-1082.

Garry, P. J., and Owen, G. M. (1967). Automated micro determination $(100 \mu \mathrm{l})$ of serum and total iron binding capacity. In Automation in Analytical Chemistry: Technicon International Symposium, p. 18. Technicon, New York.

Halliday, J. W., Gera, K. L., and Powell, L. W. (1975). Solid phase radioimmunoassay for serum ferritin.
Clinica Chimica Acta, 58, 207-214.

Hunter, W. M., and Greenwood, F. C. (1962). Preparation of iodine-131 labelled human growth hormone of high specific activity. Nature, 194, 495-496.

Hussein, S., Prieto, J., O'Shea, M., Hoffbrand, A. V., Baillod, R. A., and Moorhead, J. F. (1975). Serum ferritin assay and iron status in chronic renal failure and haemodialysis. British Medical Journal, 1, 546-548.

Lowry, O. H., Rosebrough, N. J., Farr, A. L., and Randall, R. J. (1951). Protein measurement with the folin phenol reagent. Journal of Biological Chemistry, 193, 265-275.

Luxton, A. W., Walker, H. C., Gauldie, J., Ali, M. A. M., and Pelletier, C. (1977). A radioimmunoassay for serum ferritin. Clinical Chemistry, 23, 683-689.

Marcus, D. M., and Zinberg, N. (1975). Measurement of serum ferritin by radioimmunoassay: Results in normal individuals and patients with breast cancer. Journal of the National Cancer Institute, 55, 791-795.

Miles, L. E. M., Lipschitz, D. A., Bieber, C. P., and Cook, J. D. (1974). Measurement of serum ferritin by a 2-site immuno-radiometric assay. Analytical Biochemistry, 61, 209-224.

Millbank, L., Davis, R. E., Rawlins, M., and Waters, A. H. (1970). Automation of the assay of folate in serum and whole blood. Journal of Clinical Pathology, 23, 54-59.

Ørskov, H. (1967). Wick chromatography for the immunoassay of insulin. Scandinavian Journal of Clinical and Laboratory Investigation, 20, 297-304.

Walters, G. O., Miller, F. M., and Worwood, M. (1973). Serum ferritin concentration and iron stores in normal subjects. Journal of Clinical Pathology, 26, 770-772.

Wands, J. R., Rowe, J. A., Mezey, S. E., Waterbury, L. A., Wright, J. R., Halliday, J. W., Isselbacher, K. J., and Powell, L. W. (1976). Normal serum ferritin concentration in precirrhotic haemochromatosis. New England Journal of Medicine, 294, 302-305.

Requests for reprints to: Miss Myra D. Barnett, Department of Haematology, St. Bartholomew's Hospital, West Smithfield, London EC1A 7BE, UK. 